\title{
Characterization of Cation Exchange and Cesium Selectivity of Synthetic Beta-Dicalcium Silicate Hydrate
}

\author{
S. A. El-Korashy

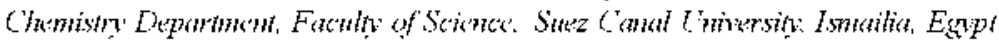 \\ (2002.8. 7 십수)
}

\section{Characterization of Cation Exchange and Cesium Selectivity of Synthetic Beta-Dicalcium Silicate Hydrate}

\author{
S. A. El-Koralshy

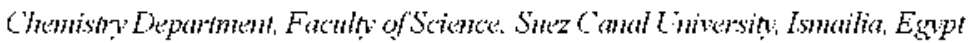 \\ (Received August 7.202)
}

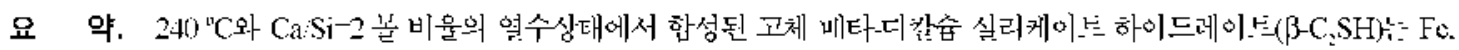

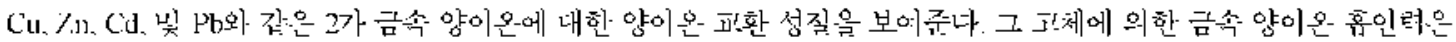

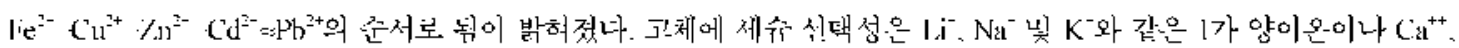

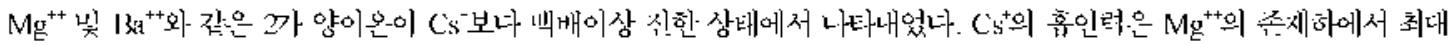

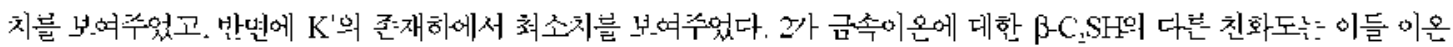
은 분러하는데 사영할 수 있다. 또한 $\beta-\mathrm{C}_{2} \mathrm{SH}$ 에 의한 금속 양이온 교환에 데한 반응겅론 및 세슴 선텍성이 연구뇌었다.

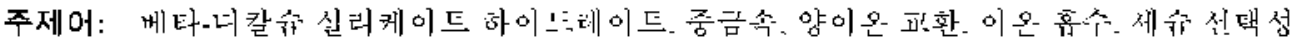

\begin{abstract}
A BSTRACT. Solid beta-dicalcium silicate hydrate $(\beta-\mathrm{C}, \mathrm{SH})$ synthesized under hydrothermal conditions at $2400^{\circ} \mathrm{C}$ and $\mathrm{Ca} \mathrm{Si-2}$ molar ratio shows cation exchange properties towards divalent metal cations such as Fe. Cu. Zn. Cd. or Pb. The ability of metal cation uptake by the solid was found to be in the order: $\mathrm{Fe}^{21}: \mathrm{Cu}^{2}: \mathrm{Zn}^{2}: \mathrm{Cd}^{21}: \mathrm{Pb}^{31}$. Cesitum selectivity of the solid was demonstrated in the presence of univalent eation such as $\mathrm{Li}^{\prime}$. $\mathrm{Na}$ and $\mathrm{K}$ and divalent cations such as $\mathrm{Ca}^{2} . \mathrm{Mg}^{2}$ and $\mathrm{Ba}^{2}$. which are one hundred times more concentrated than the $\mathrm{Cs}^{\prime}$. The uptake of $\mathrm{Cs}^{\prime}$ is maximum in the presence of $\mathrm{Mg}^{2+}$ whereas it is mimimum in the presence of $\mathrm{K}^{+}$. The diflerent allinities of $\beta-\mathrm{C}_{2} \mathrm{SII}$ towards divalent metal cations can be used for the separation of those ions. J) to to its selectivity for cesium it can be used in partitionitng of radioactive $\mathrm{Cs}^{+}$from nuclear wasles containing numerous cations. The mechanism of the metal cation exchange and cesium selestivity reactions by the solid is studied.
\end{abstract}

Keywords: Beta-dicaleium silicate hydrate. Heary metals. Cation exclange. Ion uptake. Cesium selectivity

\section{INTRODUCTION}

Various types of inorganic materials act as cation exchangers such as lavered groonium phosphates. clay minerals, hydrox̧aptities, and frame-work aluminosilicates. These materials have been recognized for potential applications due to their low cost of preparation and remárkable ion selective properties towards a large number of metal cations from solution. The applications vary from their use in water sottening, Fettilizer, catalysis to living of hayardous isotopes in cement and concrete matrix materials ${ }^{1-0}$ Some authors have reported that some calcium silicate hydrate compounds prepared under 
hydrothermal treatment, mainly 1.1 nm-tobemorites; $1.1 \mathrm{~nm}-\mathrm{j}(\mathrm{m}$ substituted tobmonorites, sonotlite and $\mathrm{CSH}^{r^{*} !}$ (I), act as cation exchanger with some metal cations with $\mathrm{Ca}^{2-} \mathrm{or} \mathrm{S}^{+-}$in their lattice structures ${ }^{3-2}-15$ and leading to their anomphization. 3. 1. 15

Beta-dicalcium silicale hydrate $\left(3-\mathrm{C}_{2} \mathrm{SH}\right)\left(\mathrm{Ca}_{2} \mathrm{SiO}_{4}\right.$ $\mathrm{H}_{2} \mathrm{O}$ ) occurs in nature, usually as a white fibrous mineral known as hillebrandite. ${ }^{\text {Is }}$ Synthetic $\beta-\mathrm{C}_{2} \mathrm{SH}$ was prepared from a mixture of tricalcium silicate and silicic acid ${ }^{17}$ as well as silica ${ }^{18}$ by means of hydrothermal process. On heating. $\beta$-C.Sll starts to decompose at about $500^{\circ} \mathrm{C}$ and produces poorly crystalline and chemically pure $\beta-C$, s that is stable at room temperature without the addition of any chomical stabilizers. ${ }^{18} \beta-\mathrm{Ca}_{2} \mathrm{SiO}_{4}$ is considered as mo of the important constituent compounds of portland cement and generally synthesises by hightempurature solid state reaction of $\mathrm{CaO}^{\circ}$ and $\mathrm{SiO}_{2}$ at about $1400^{\circ} \mathrm{C}$.

P'owder X-ray diffiaction (XIRD) studies of natul$\mathrm{ra}^{10}$ and synthetic [18] $\beta$-C sisll revealed a monoclinic structure. but recent studies by Youn ot al ${ }^{10}$ suggested that the crystal structure of $\beta-C_{2}$ SI I may be triclinic, rather than moneclinic stmmetry and analogons analogy with wollastonite $\left(\mathrm{CaO} \cdot \mathrm{SiO}_{2}\right)$ compound. Rusults of silicate anion strueture of synthetic $\beta-C_{2} \mathrm{SH}$ reported by Ishida et at. ${ }^{18}$ using ${ }^{2} \mathrm{Si}$ MASNMR lechnicue showed that single dricrkette (single chains containing three tetrahedra per unit cell) alppeared single ehemical shith at $-86.5 \mathrm{ppm} \mathrm{Q}^{2}$.

The objectives of this work here are (a) to determine the cation exchange capacity of synthetic $\beta$ $\mathrm{Ca}_{2} \mathrm{SiO}_{4} \cdot \mathrm{I}_{2} \mathrm{O}$ prepared under hydrother-mal treatment toward some heary metal cations and (b) to deteminine the cesium [ $\mathrm{Cs}^{13-}$ ] selectivity of this solid from different solutions containing alkali and alkaline carth caltons. This work was undertaken in order to fully realise polentialities of this inorganic cation exchanger for the treatment of various metallic calions in solutions and nuclear waste (as cesium) disposal arcas.

*C $\mathrm{C}-\mathrm{CaO} . \mathrm{S}^{-} \mathrm{SiO}_{2} \cdot \mathrm{H}^{-} \mathrm{H}_{2} \mathrm{O}$

\section{EXPERIMENTAL AND METHODS}

\section{Starting Materials}

The starting materials were mixlures of $\mathrm{CaO}$ with quart\% $\left(99.75 \% \mathrm{SiO}_{2}\right.$ mean particle side below $\left.45 \mu \mathrm{m}\right)$. The $\mathrm{CaO}$ was made from $\mathrm{CaCO}_{3}$ (BDH reagent - grade) by heating at $1050^{\circ} \mathrm{C}$ lor $3 \mathrm{~h}$

\section{Synthesis of $\beta-\mathrm{C}_{2} \mathrm{SH}$}

Solid $\beta$-C $\mathrm{s}$ sl was sythesized by mixing stoichiometric amounts of $\mathrm{CaO}$ and cuartz at a molar ratio equal to two. The solid was added to 20 times of its weight of decarbonated deionized water and stirred for $15 \mathrm{~min}$. The content was quantitatively translemed to a stainless sted autodare bomb $\left(250 \mathrm{~cm}^{3}\right)$ intemally coated with tellon. The autoclave was placed in a manually controlled electrically healed oven, and the temperature was raised gradually to $240^{\circ} \mathrm{C}$ and kept at this temperature for 6-days. At the end of the run the autoclare was cooled showly until room temperature, and the content was washed with distilled water $(10 \mathrm{ml})$ and dried at $80^{\circ} \mathrm{C}$ for $24 \mathrm{~h}$. The solid was characterized by X-ray powder diffraction. SEM, with EDAX, DTA-TG and FIIR spectroscopy and chemical analysis.

\section{Cation exchange capacity (CEC) of $\beta-\mathrm{C}_{2} \mathrm{SH}$}

The C.T. $(\mathrm{mec} / \mathrm{gm})$ of $\beta-\mathrm{C}_{2} \mathrm{SH}$ solid was determined by using the method reported previously. ${ }^{-1}$ The proeedure can be brietly deseribed as follows: $50 \mathrm{mg}$ of the solid was washed twice (equilibration lime was 30 min. For each washing) with $\mathrm{KCl}$ k) salurate all the exchange siles with $\mathrm{K}$, followed by washings with $0.02 \mathrm{~N} \mathrm{KCl}$ tive times to remove the excess of KCl to prevent hydrolysis. The $\mathrm{K}$ ions from the exchange sites were displaced by washings (30) min. equilibration time per washing) with $0.2 \mathrm{~N}$ $\mathrm{CsCl}$ four times. The solution was collected and analyzed for $\mathrm{K}^{-}$by $\Lambda$ ES and the total CEC was determined.

\section{Cesium selectivity in the presence of alkali and alkaline earth cations}

The selective exchange was measured by the following proceduce reported in [3]: $25 \mathrm{ml}$ of $0.02 \mathrm{~N}$ chloride solutions of $\mathrm{M}^{\prime \prime}$ (T.i, Ná, K, Már: Cá or Bá) containing $2 \times 10^{\prime} \mathrm{N} \mathrm{CsCl}$ was added to $25 \mathrm{mg}$ of $\beta-C_{2} \mathrm{SII}$ solid in $50 \mathrm{ml}$ glass bottle. The misture 
was equilibrated for $24 \mathrm{~h}$ at $25^{\prime \prime} \mathrm{C}$. Triplicates were used for each cation. After equilibration, the solid and solution were separated. The concentration of cesium ion was analyzed by atomic absorption spectroscopy (AAS) using Perkin-LImer PL: 703 instrument.

\section{Cation exchange reaction experiments}

CEC reaction experiments were conducted as follows: $20 \mathrm{mg}$ of each solid were equilibrated for different periods $(\mathrm{l}-24 \mathrm{~h}$ ) in glass vials with $10 \mathrm{ml}$ of $\mathrm{Cl}^{-}, \mathrm{SO}_{4}^{--}$or $\mathrm{NO}_{3}^{-}$solution of $200,400,800$ or $1000 \mathrm{ppm}$ of $\mathrm{Fe}^{21}, \mathrm{Cu}^{2}, \mathrm{Zn}^{21}, \mathrm{Cd}^{21}$ or $\mathrm{Pb}^{21} ; \mathrm{NO}^{-}$ was used for $\mathrm{Pb}^{21}: \mathrm{Cl}^{-}$for $\mathrm{Cd}^{21}$ and $\mathrm{SO}_{+}{ }^{2}$ for $\mathrm{Cu}^{21}$, $\mathrm{Fe}^{21}$ or $\mathrm{Zn}^{2}$. After different periods of equilibration. the solid phases in the glass vials were separated by centrifugation, and a part of the supematant solution was collected for chemical analysis using AAS. The $\mathrm{pH}$ of the equilibrium solutions for each reaction in the glass vials was immediately measured.

\section{Characterization of the solids}

The $\beta-\mathrm{C}_{2} \mathrm{SH}$ exchanger and the solids after exchange reactions were dried at $60^{\circ} \mathrm{C}$ in oven for $24 \mathrm{l}$ and characterized by DTA-TG Perkin-Elmer 7 series thermal analysis system in the range $50-1100^{\circ} \mathrm{C}$ using a heating rate of $10^{\prime \prime} / \mathrm{min}$. XRD a Scintag/ AVX 3100 XRD system with CuK radiation and $^{2}$ F[IR using NiColet F[-]R Magna-IR 560 were used. A JLOL scanning electron microscope JSM-5600 attached with an energy dispersive X-ray (ISIS OXFORD) source was used for determining particle size, microstructure and chemical composition.

\section{RESULTS AND DISCUSSION}

Powder XRD analysis ( $F$ ig. I) showed that one single phase of $\beta-C_{2} S H$ formed with matches ASTM card no. 11-594. This phase consisted of aggregates of fibrous crystals as examined by SLM ( $/ \mathrm{ig}$. 2) and decomposes in the range of $490-660^{\circ} \mathrm{C}$ as determined by D'TA-TG ( $/ \mathrm{Fg} .3$ ) and forms $\beta-\mathrm{C}_{2} \mathrm{~S}$.

The chemical composition and cation exchange capacity (CEC) of $\beta-\mathrm{C}_{2} \mathrm{SH}$ are given on Table 1 .

The total value of $\mathrm{CEC}$ of $\beta-\mathrm{C}_{2} \mathrm{SH}$ based on $\mathrm{K}^{+}$ exchange is $0.287 \mathrm{meq} / \mathrm{g}$ and represents the extent of reversible exchange reaction.

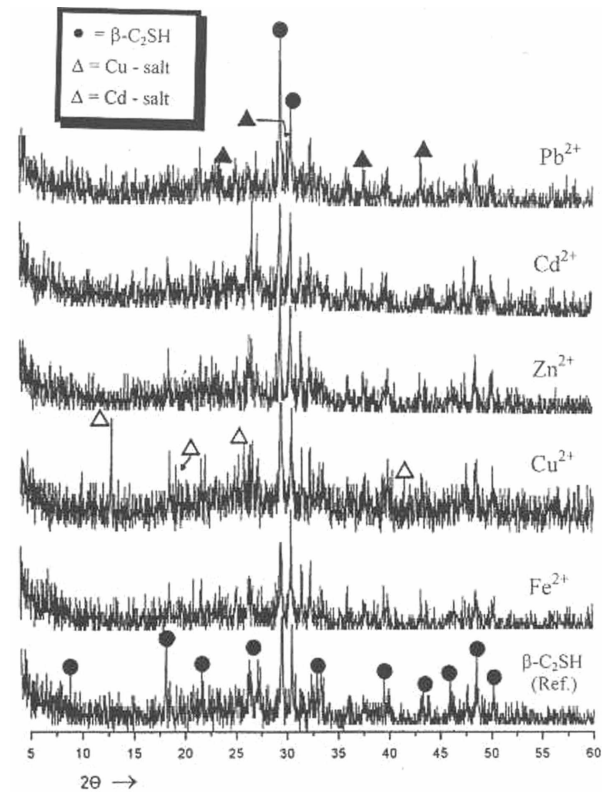

Fig. 1, XRJ) patterins of $\beta-(\mathrm{CSH}$ reacted with $1000 \mathrm{ppm}$ of $\mathrm{He}^{2+},\left(\mathrm{Cu}^{2+}, 7 \mathrm{n}^{2-}, \mathrm{Cd}^{2-}\right.$ or $\mathrm{l}^{3} \mathrm{~d}^{2+}$ for $24 \mathrm{~h}$.

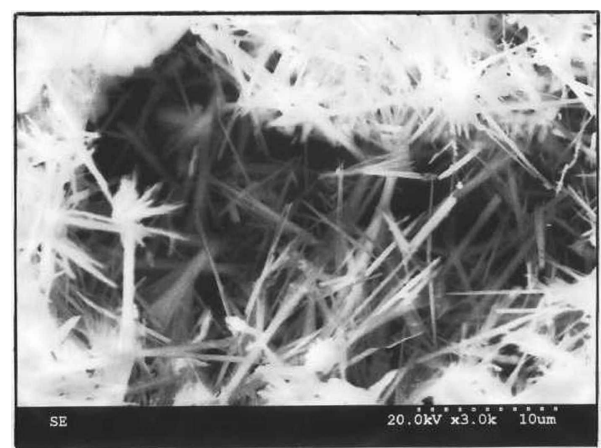

Fig. 2. SF.M Ihotographs of synthesized $\beta-\mathrm{C} . \mathrm{SH}$ crystals.

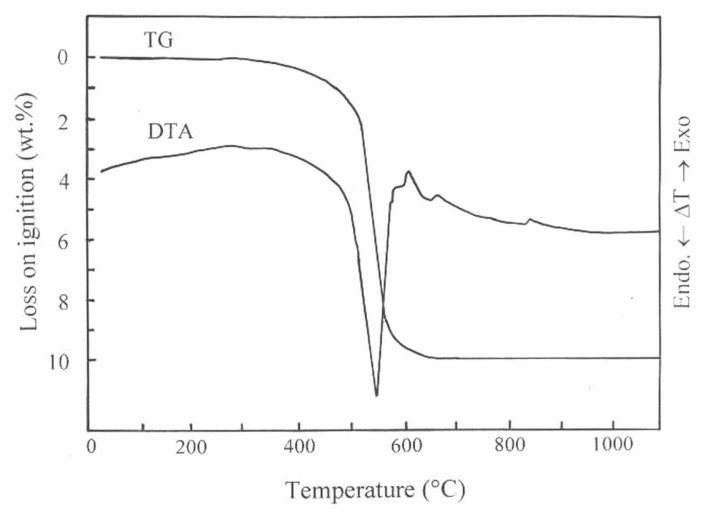

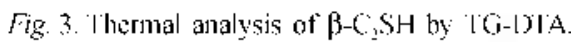


Table I. Chemical composition and CEC of $\beta-C_{i}$ SII

\begin{tabular}{ccc}
\hline \hline Solid & Chemical composition & CFC meq $\mathrm{g}$ \\
\hline$\beta-\mathrm{C}_{i} \mathrm{SIJ}$ & $\mathrm{Ca}_{2.01} \mathrm{Si}_{096} \mathrm{O}_{3, y}-1.03 \mathrm{H}_{i} \mathrm{O}$ & 0.287 \\
\hline
\end{tabular}

Tabk $2 . \mathrm{Cs}^{+}$selecir ity (melg) and distribution axellicient from different cationic solution

\begin{tabular}{ccc}
\hline \hline Metal jon misture & Cs $^{+}$taken up (meq g) & \multicolumn{1}{c}{$\mathrm{K}_{\mathrm{d}}$} \\
\hline $\mathrm{Cs}: \mathrm{Mg}$ & 0.2289 & 3667 \\
$\mathrm{Cs}: \mathrm{I}$ i & 0.2115 & 14973 \\
$\mathrm{Cs} \mathrm{Ca}$ & 0.2077 & 10055 \\
$\mathrm{Cs}: \mathrm{Na}$ & 0.1576 & 18181 \\
$\mathrm{Cs} \mathrm{Ba}$ & 0.1205 & 9440 \\
$\mathrm{Cs}: \mathrm{K}$ & 0.082 .3 & 9055 \\
\hline
\end{tabular}

Cesium selectivity values in the prexence of dillertnt competing cations are shown in Table 2 and they increase as lollows: $\mathrm{Mg}>\mathrm{I}, \mathrm{i}>\mathrm{C} a>\mathrm{Na}>\mathrm{Ba}>\mathrm{K}$.

The maximum selectivity uptake of $\mathrm{C}^{\prime} \mathrm{s}^{\prime}$ is about $0.23 \mathrm{mec} / \mathrm{g}$ in the presence of $\mathrm{Mg} \mathrm{g}^{2}$ whereas it is minimum in the case of $\mathrm{K}$ ions. 'This shows that the $\mathrm{K}^{\prime}$ is the most competing and $\mathrm{Mg}^{21}$ is the least competing with $(S$ ' toward the exchanger: 'The distribution coefficient $\left(K_{11}\right)$ for $C$ s between the exchanger and solution phase of $\mathrm{M}^{n+}(\mathrm{n}=2$ or 1$)$ was calculated using Eq. (1) [3]:

$$
\begin{gathered}
\mathrm{K}_{\mathrm{d}}-\frac{\text { fraction of cation on ion exchanger }}{\text { fraction of cation in solution }} \\
\times \frac{\text { mll of solution }}{\mathrm{g} \text { of ion cxchanger }}
\end{gathered}
$$

An examination of cesium seloclivity (Table 2) shows that the uptake is related to the hydration sta- tus of the cations. I lighly hydrated $\mathrm{Mg}^{2+}$ and $\mathrm{Li}^{-}$ ions are excluded while less hydrated $\mathrm{C}^{-}$and $\mathrm{K}^{-}$ are preferentially taken on the surlaee of $\beta-\mathrm{C}_{2} \mathrm{SH}$ strueture. In this respect. Shrivatala et at. ${ }^{3}$ considared that $\mathrm{Cs}^{+}$selectivity (in the prexine of alkali metals) by synthetic (Na+Al)-tobemeries depends upon hydration status of the concerned cation and the steric limitation of tobermorite structure. The uptake of $\mathrm{C} s$ is reversible ion exchange reaction ${ }^{20}$ resulting in release of equivalent $\mathrm{Na}$ from the interlavers of tobemorite or $\mathrm{Ca}^{2}$ in case of unsubstituted tobermorite.

The pI I-value of the initial cation metal solutions varied with the type of salt (Iable 3). This change is attributed to the degree of release of $\mathrm{Ca}^{2-}$-ions from the structure of the $3-\mathrm{C}_{2} \mathrm{SH}$ solid in solution to from hydrate calcium ions during the reaction. $12-15$

Rexults of the exchange reation of $\mathrm{Fe}^{2}, \mathrm{Cu}^{21}, 7 \mathrm{n}^{21}$, $\mathrm{Cd}^{2}$ or $\mathrm{Pb}^{21}$ with $\mathrm{Ca}^{2}$ in $\beta-\mathrm{C}_{2} \mathrm{SH}$ are prexented in Figs. (4-8). Generally, the amount of metal ions taken up by $\beta-C_{2} \mathrm{SH}$ I increases with increasing reaction time and/or initial concentration in the order: $\mathrm{Fe}^{21}>\mathrm{Cu}^{2}>\mathrm{Zn}^{21}>\mathrm{Cd}^{2} \approx \mathrm{Pb}^{2}$.

In these reactions the exchange of $\mathrm{Ca}^{2-} \Leftrightarrow \mathrm{M}^{2-}$ was found to be non-stoichiometric. Generally, the uptake ol $\mathrm{M}^{2+}$ by the solids was higher than $\mathrm{Ca}^{2+}$ ions released. with increasing reaction time or metal ion concentration (Figs. 4-8)

The non-sitoichiometry anises from limited partial hydrolysis of $\beta-C_{2} \mathrm{SH}$ silicale chains (Fig. 9). This is due to the acidie nature of the $\mathrm{M}^{2}$-solulions: cspecially in the case of $\mathrm{Fe}^{21}, \mathrm{Cu}^{2}$ or $\mathrm{Pb}^{21}$ ions (Table 3)

\begin{tabular}{|c|c|c|c|c|c|c|c|c|c|c|c|c|c|c|c|c|c|c|c|c|}
\hline \multicolumn{21}{|c|}{ Metal Cation } \\
\hline \multirow{3}{*}{$\begin{array}{l}\text { Reaction } \\
\text { time h }\end{array}$} & \multicolumn{4}{|c|}{$\mathrm{Fe}^{\mathrm{A}}$} & \multicolumn{4}{|c|}{$\mathrm{Cu}^{2+}$} & \multicolumn{4}{|c|}{$\angle n^{2-}$} & \multicolumn{4}{|c|}{$P^{\prime} b^{2-}$} & \multicolumn{4}{|c|}{$\mathrm{Cd}^{2-}$} \\
\hline & \multicolumn{20}{|c|}{ Conc (ppm) } \\
\hline & 200 & 400 & 800 & 1000 & 200 & 400 & 800 & 1000 & 200 & 400 & 800 & 1000 & 200 & 400 & 800 & 1000 & 200 & 400 & 800 & 1000 \\
\hline 0 & 2.04 & 1.87 & 1.69 & 1.53 & 5.03 & 4.76 & 4.57 & 4.41 & 601 & 5.54 & 6.05 & 609 & 5.01 & 4.80 & 4.91 & 4.95 & 6.17 & 6.01 & 6.18 & 6.25 \\
\hline 1 & 2.45 & 2.04 & 1.89 & 1.68 & 9.40 & 5.81 & 5.05 & 4.75 & 6.80 & 6.65 & 6.41 & 6.37 & 6.40 & 6.35 & 6.09 & 6.60 & 7.16 & 6.62 & 6.43 & 6.35 \\
\hline 6 & 2.54 & 2.44 & 1.94 & 1.82 & 9.55 & 6.77 & 5.08 & 4.85 & 6.78 & 6.59 & 6.44 & 6.37 & 7.29 & 5.86 & 6.00 & 6.09 & 7.18 & 7.30 & 7.14 & 7.20 \\
\hline 12 & 2.69 & 2.56 & 2.10 & 1.95 & 9.45 & 5.8 .3 & 5.25 & 4.95 & 687 & 668 & 6.43 & 6.40 & 8.05 & 9.4 .3 & 6.05 & 6.79 & 7.60 & 7.25 & 7.12 & 7.00 \\
\hline 24 & 2.98 & 2.69 & 2.24 & 2.05 & 9.43 & 5.88 & 5.29 & 4.97 & 697 & 6.79 & 6.49 & $6 . .38$ & 7.58 & 9.57 & 7.51 & 6.04 & 6.65 & 6.54 & 6.45 & 6.44 \\
\hline
\end{tabular}

Toble 3. pII ralues of reacted metal solutions 

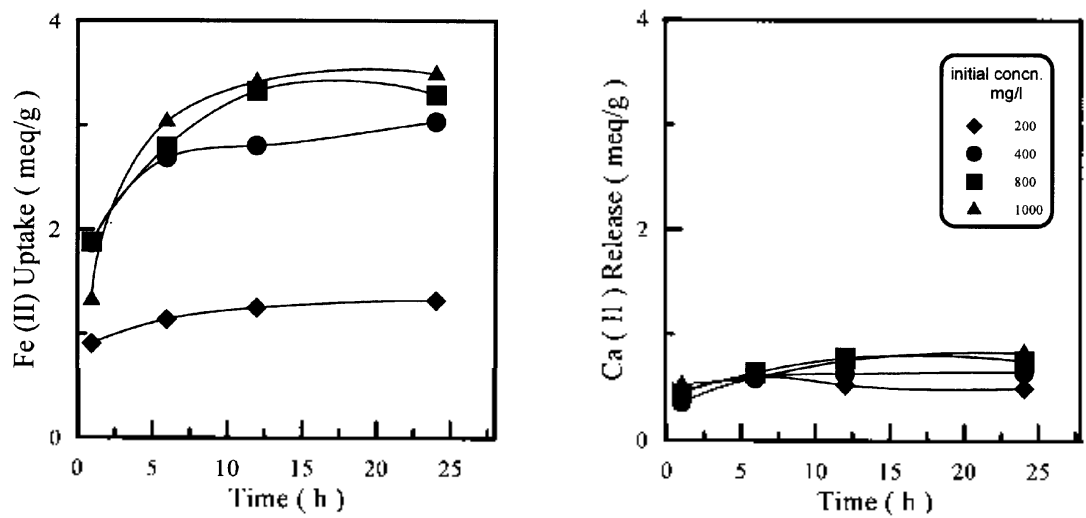

Fig. 4. Fttect of concentration and time on Fe(II) uptake and (Cat JI) from $\beta$-dicalcium silicate hydrate.
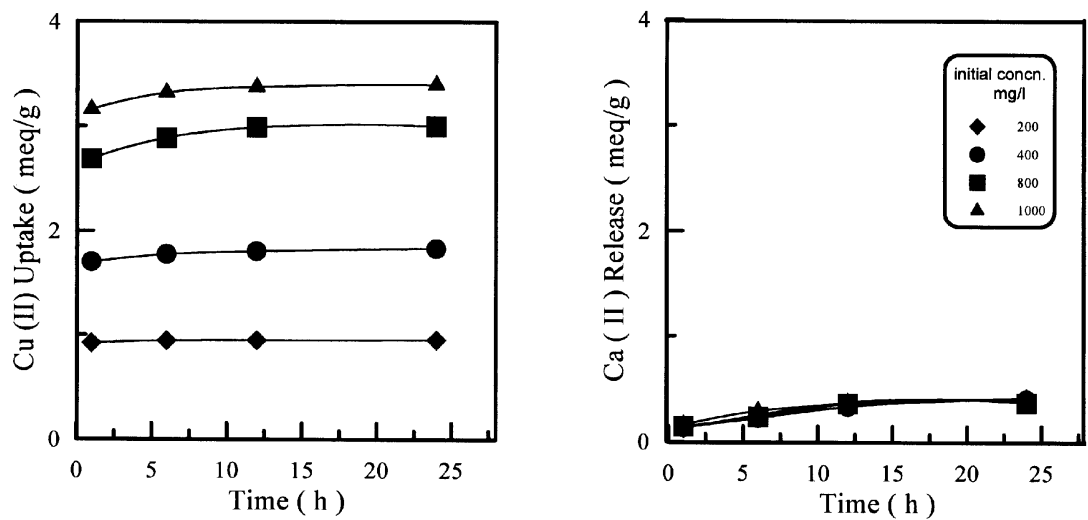

Fig. 5. Fffiect of concentration and time on ('u(II) uptake and ('at II) from $\beta$-dicalcium silicate hydrate.
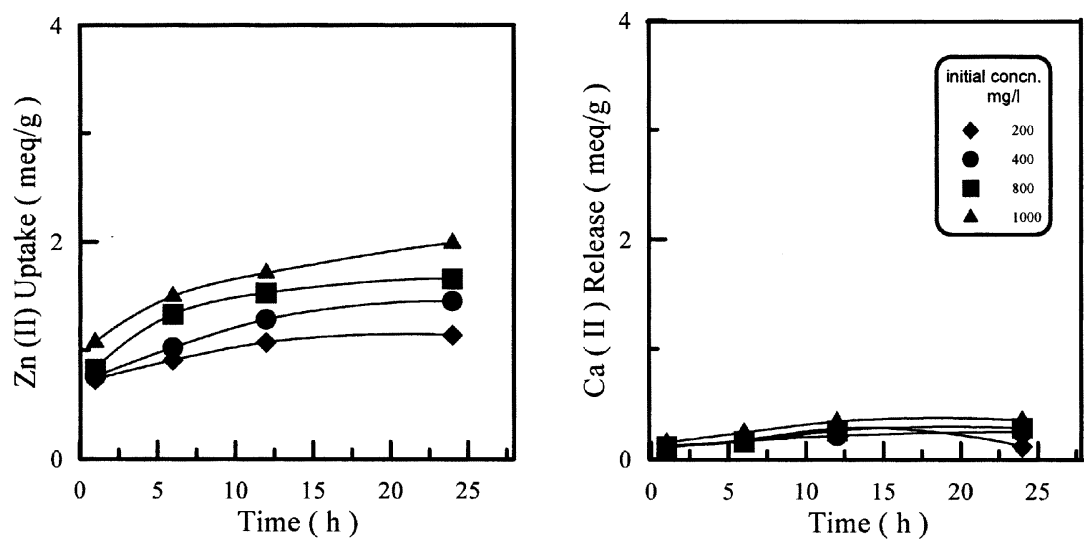

Fig. 6. Effect of concentration and time on $\mathrm{Zn}(11)$ uplake and $\mathrm{Ca}(11)$ from $\beta$-dicalcium silicate hydrate

and the basic nature of the solid. Accordingly, extra $\mathrm{Ca}^{2-}$-ions and little mounts of (med $\left(\mathrm{g}\right.$ ) of $\mathrm{Si}^{+-}$were detected in solutions. Part of the total $\mathrm{Ca}^{2+}$ ions liberated from structure reacted with free $\mathrm{SO}_{+}^{2-}$ (in case of le, $\mathrm{Cu}$ and $/$ or $\mathrm{Zn}$ salts) to form insoluble $\mathrm{CaSO}_{\downarrow}$, which was confirmed by measuring the free $\mathrm{SO}_{\downarrow}^{2}$ after the reaction. The remaining $\mathrm{Ca}^{2+}$-ions apparently exchanged with metal ions $\left(\mathrm{Ca}^{\bar{i}} \Leftrightarrow \mathrm{M}^{i-}\right)$. On 

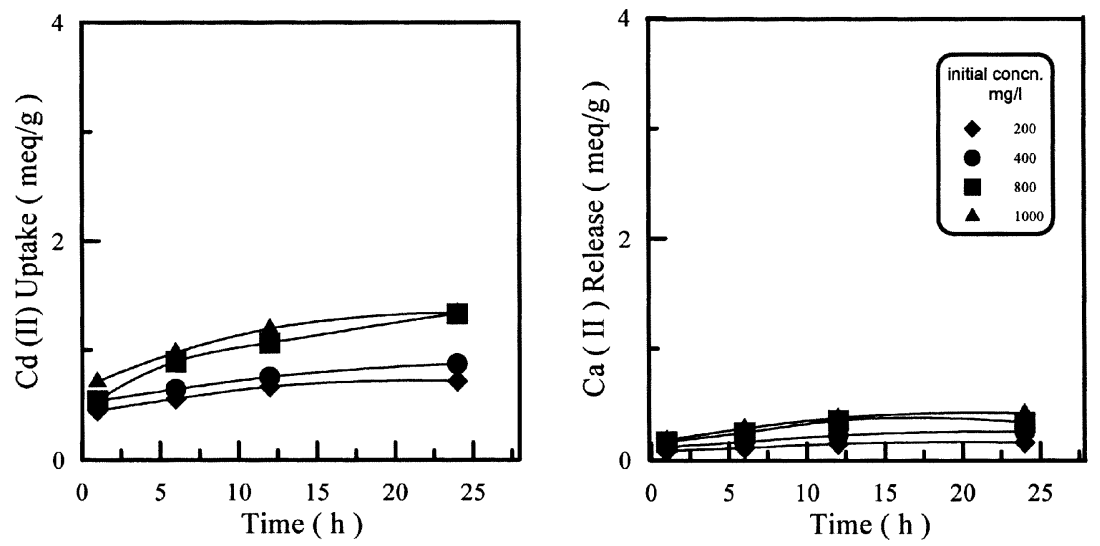

Fig. 7. Fffect of concentration and time on (d(II) uptake and (Cat II) from B-dicalcium silicate hydrate.
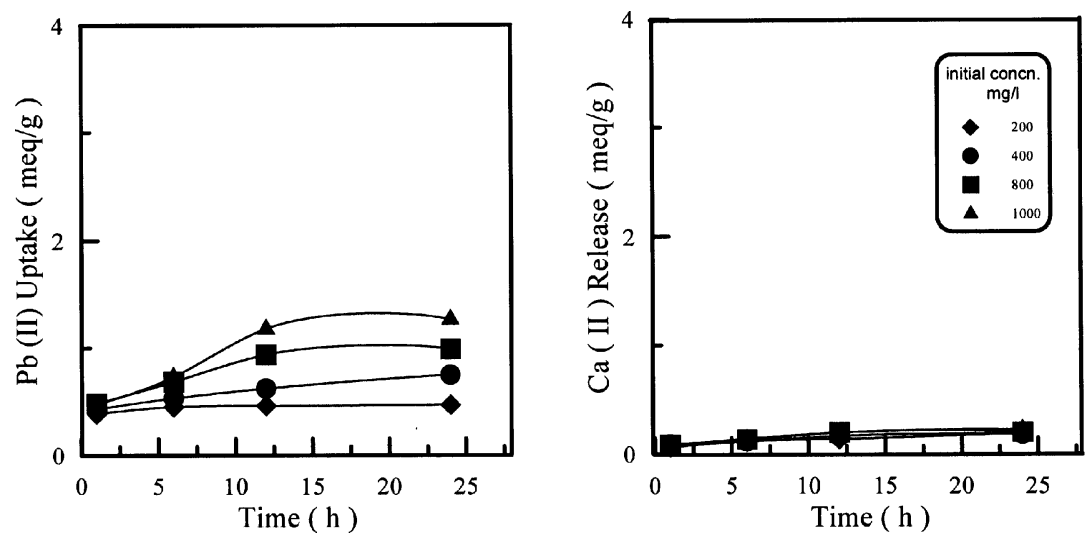

Fig. 8. Fffect of concentration and time on Pd(II) uptake and (at JI) from $\beta$-dicalcium silicate hydrate.

the other hand $\mathrm{Si}^{+}$was measured by molybdenum blue photo-metric method, ${ }^{12}$ so that it is difficult to draw precisely the relationship between the exact amounts of $\mathrm{Ca}^{2+}$ exchanged with $\mathrm{M}^{7+}$.

In addition. some of these cations, such as $\mathrm{Cu}^{2-}$ and $\mathrm{Cd}^{2-}$ formed precipitates which were detected by XRD ( $F i g$. I), while no precipitates were detected with $\mathrm{Fe}^{2 \cdot}, \mathrm{Zn}^{2 \cdot}$ and $\mathrm{Pb}^{2}$ by XRD. This may be in amorphous state as in precipitation of $\mathrm{Zn}^{2}$ on the surface of $\beta-C_{2} \mathrm{SH}$ crystals as shown in SEM micrograph ( $/ \mathrm{ig} .10 \mathrm{a})$ and confirmed by LDAX ( $/ \mathrm{ig} .10 \mathrm{~b})$. All the above factors are responsible for non-stoichiometry of $\mathrm{Ca}^{21} \Leftrightarrow \mathrm{M}^{21}$ exchange as shown in /\%g. 4-8.

The reaction of these cations leads to a partial loss of crystallinity of $\beta-\mathrm{C}_{2} \mathrm{SH}$ as can be deduced from the decrease of the relative intensities of $d$ spacing as can be seen in case of $\mathrm{Fe}^{2-}$ and $\mathrm{Cd}^{2-}$ with respect to the reference ( $/ \%$. 1$)$.

The exchange reaction mechanism $\left(\mathrm{M}^{2+} \Leftrightarrow \mathrm{Ca}^{i-}\right)$ in $\beta-\mathrm{C}_{2} \mathrm{SH}$ may take place between $\mathrm{M}^{2+}$ and $\mathrm{Ca}^{2+}$ which is on the surface and edge sites linked with $\mathrm{Si}-\mathrm{O}$ chains (Fig. 9) as in case of $\mathrm{CSH}(\mathrm{I})^{15}$ or tobermorite $\left(\mathrm{Ca}_{5} \mathrm{~S}_{\mathrm{H}_{11}} \mathrm{H}_{5}\right)[8,13,14]$. In the latter, the basic layer structure consists of double layers silicate anjons, while $\beta-\mathrm{C}_{1} \mathrm{SH}$ has a single chain structure (Fig. 9). ${ }^{18}$

The metal ions uptake phenomenon by the $\beta-\mathrm{C}_{1} \mathrm{SH}$ solid appears to be from both partial exchange $\left(\mathrm{Ca}^{21}\right.$ $\Leftrightarrow \mathrm{M}^{21}$ ) and immobilization (precipitation). So it is difficult to delineate the extent of cation exchange from the precipitation of these cations during the course of reaction. Precipitation of these cations as salts on the surface of $\beta-\mathrm{C}_{2} \mathrm{SH}$ as in the case of $\mathrm{Cu}^{2+}$ and $\mathrm{Cd}^{2-}$ (as detected by XRD, Fig. I) and $\mathrm{Zn}^{2-}$ (as 


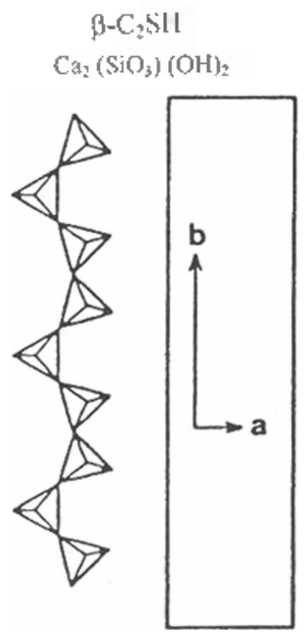

Fig. 9. Schematic diagram shows the single drictte anion structure of $\beta-C_{2} S I|| 18 \mid$.
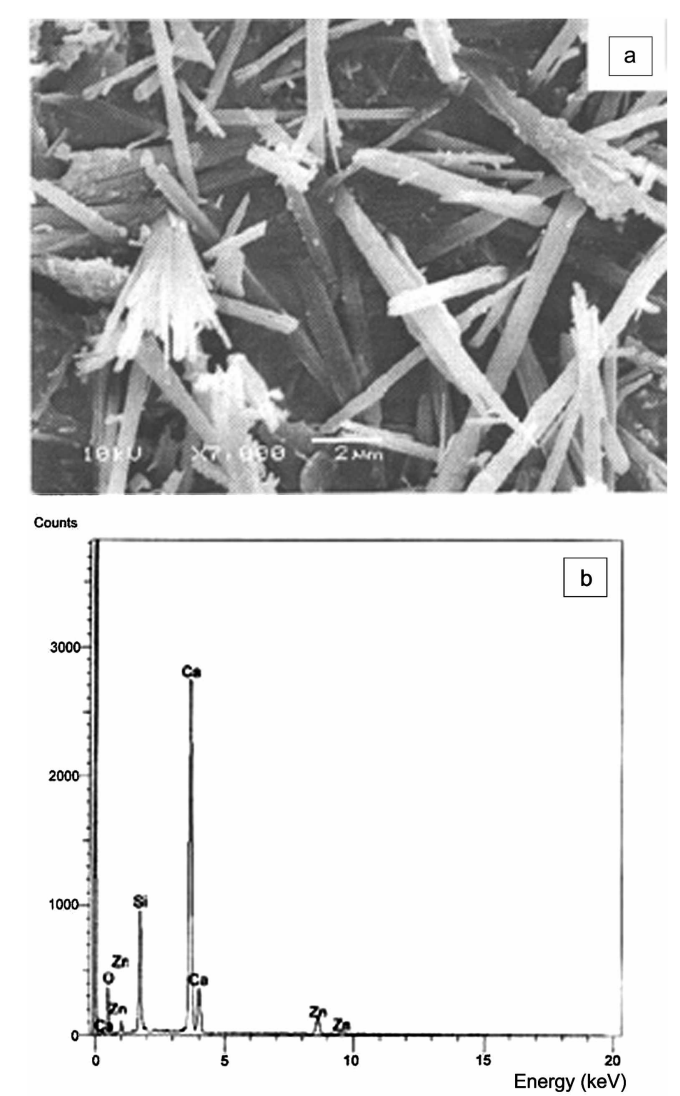

Fig. 10. (a) SEM of $\beta-C_{2}$ SI I reacted with $1000 \mathrm{ppnn} \mathrm{Zn}^{2}$ solution for $24 \mathrm{~h}$ : (b) EDAX of $\beta-C_{2} \mathrm{SI}$ t reacted with $1000 \mathrm{ppm} \% \mathrm{~s}^{2+}$ tor $24 \mathrm{~h}$.
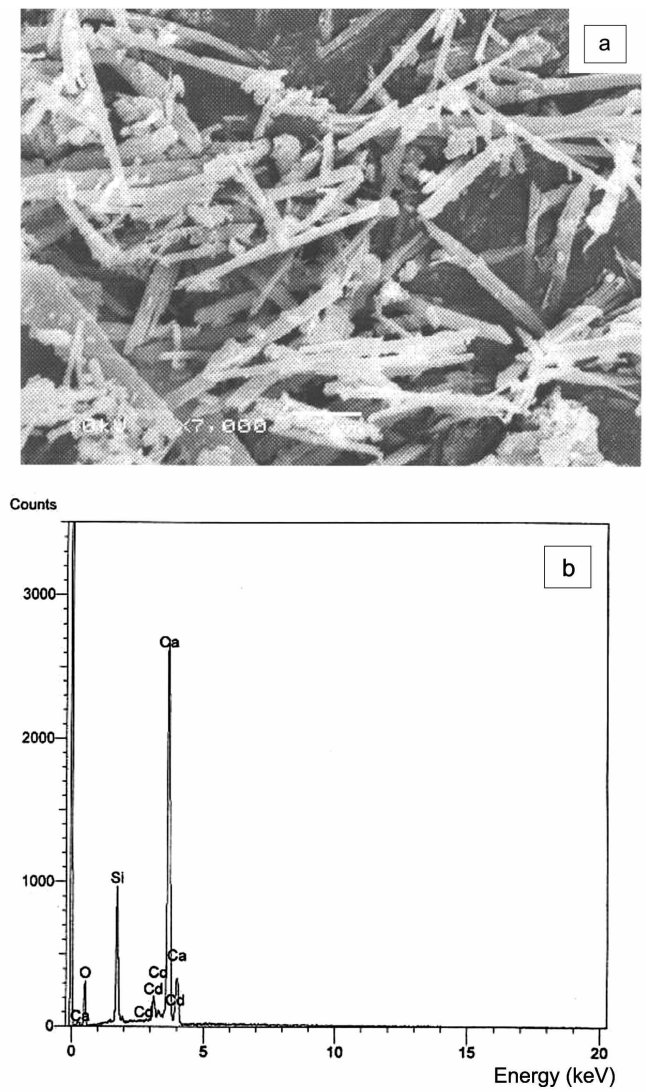

Fig. 11. (a) SHM of $\beta-\mathrm{CSH}$ reacted with $1000 \mathrm{ppm} \mathrm{Cd}^{2}$ solution lor $24 \mathrm{~h}$ : (b) EDAX of $\beta-C$ SII reacted with

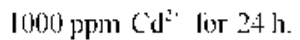

detected by SLM with LDAX, fig. 10 a \& b), requires a relatively basic mediun. This is achieved by the liberation of hydrated $\mathrm{Ca}^{2+}$ from the lattice structure of the solid (due to $\mathrm{Ca}^{i^{-}} \Leftrightarrow \mathrm{M}^{3+}$ ), thus elevating the $\mathrm{pH}$ values (Table 3 ).

The reaction of the above mentioned cations with $\mathrm{B}-\mathrm{C}_{2} \mathrm{SH}$ leads to a partial loss of crystallinity as can be deduced from the decrease of the relative intensities of d-spacing with respect to the reference (Fig. 1) and the results of microstructures are presented in $/ \mathrm{ig} .10 \mathrm{~b}$ and $11 \mathrm{~b}$. 'The most intense Jill absorption bands of $\mathrm{B}-\mathrm{C}_{2} \mathrm{SH}$ (Fig. 12), slightly decrease. especially those located at 1077, 1030, 945,901 and $454 \mathrm{~cm}^{3}$ upon reaction with $\mathrm{Cd}^{i^{-}}$. The positions of some these are slightly shifted. may be attributed to some modification in the structure, due to $\mathrm{Ca}^{2+} \Leftrightarrow \mathrm{Cd}^{3+}$ exchange. Presence of very 


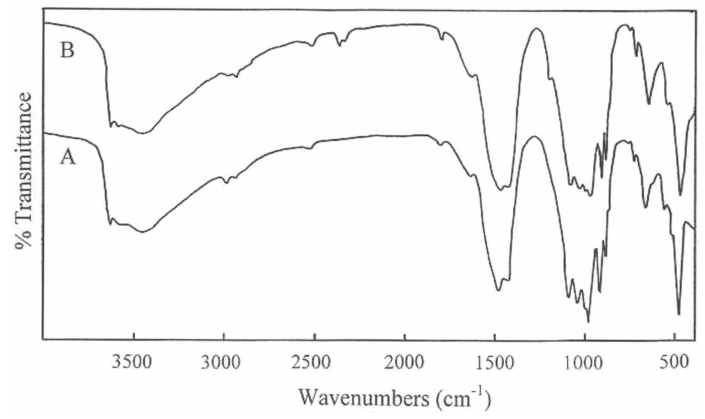

Fig. I2. FTIR spectral of synthesized $\beta$-C.SI I (a) and $\beta$-C.SH reacted with $1000 \mathrm{ppm} C \mathrm{Cd}^{\prime \prime}$ (b) for $24 \mathrm{~h}$.

weak sharp band at about $3618 \mathrm{~cm}{ }^{1}$ confirms the presence of $\mathrm{OH}^{-}$groups which are bound in the structure; while the presence of broad band located at 3445 and weak one at $1630 \mathrm{~cm}$ ' may due to the physically adsorbed water.

Scanning electron microscopy (SEM) results of $3-\mathrm{C}_{2} \mathrm{SH}$ reacted with $1000 \mathrm{ppm} \mathrm{Zn}^{1+}$ and $\mathrm{Cd}^{7+}$ solutions for $24 \mathrm{~h}$ (Fig. 10a and 1la) support the XRD and FTIR data. They also show that the crystallinity does not completely remain intact upon exclange. especially in the case of $\mathrm{Cd}^{21}$ ( Fig. $10 \mathrm{a}$ ).

The energy dispersive analysis X-ray (EDAX) data of the above samples are given in $F$ igs. ( $10 \mathrm{~b} \&$ $11 \mathrm{~b})$. Fig. 10(b) demonstrates the existence of $\mathrm{K}_{u t}$ radiation of $\mathrm{Ca}, \mathrm{Si}$ and $\mathrm{Zn}^{2}$, while $\mathrm{l} \mathrm{l}(\mathrm{b})$ demonstrates the existence of $\mathrm{K}_{\mathrm{ar}}$ radiation of $\mathrm{Ca}, \mathrm{Si}$ and $\mathrm{Cd}^{2-}$. This supports the release of some of the total $\mathrm{Ca}^{2-}$ ions present in the crystal structure of $\beta-\mathrm{C}_{2} \mathrm{SH}$ due to exchange with $\mathrm{Zn}^{2-}$ or $\mathrm{Cd}^{2-}$.

In conclusion, beta-dicalcium silicate hydrate prepared under hydrothermal conditions at $\mathrm{Ca} \mathrm{Si}^{-} 2$ (molar ratio) exhibits selectivity for cesium and this selectivity increases in different cations solutions of alkali metals and alkaline metals as follows: $\mathrm{Mg}^{2}>$ $\mathrm{Li}^{1}>\mathrm{Ca}^{2}>\mathrm{Na}^{\prime} \approx \mathrm{Ba}^{2}>\mathrm{K}$. The selectivity of the $\mathrm{Cs}^{\prime}$ depends on the hydration status of the present cation in solution. It can be used in partitioning of radioactive $\mathrm{Cs}^{\prime}$ from nuclear wastes containing numerous cations. The $\beta-\mathrm{C}_{2} \mathrm{SH}$ has a cation exchange capacity equal to $0.287 \mathrm{meq} / \mathrm{g}$, so it can be used as cation exchanger for the separation of heavy metals from the hazardous waste stream. The amount of removal of heavy metal ion by $\beta-C_{2} S H$ increases in the order: $\mathrm{le}^{2 \cdot}>\mathrm{Cu}^{2-}>\mathrm{Zn}^{21}>\mathrm{Cd}^{21} \approx \mathrm{Pb}^{2-}$. The total cations uptake is appeared to be due to both exchange of $\mathrm{Ca}^{2} \Leftrightarrow \mathrm{M}^{2 \cdot}$ and immobilization (precipitation) of $\mathrm{M}^{i^{-}}$as salts.

\section{REFERENCES}

I. Suzuki. T.: I latsuchika. T.: Miyake. M. J. Chem. Soc. Fanadan: Frans. 1984. I80. 3157.

2. Komarneni. S.: Roy. D. M. Scientitic Bersis for Nuclear Waste Management. Brookins D. (j. (Ed.) Elsevier. New York. 1983. 5. 55.

3. Shrivastava. O. P.: Komerneni. S. Cem. Concr. Res. 1994. $24(3) .573$.

4. Macias. A.: Kindness. A.: Glasser. F. R? Cem Concr: Res.. 1997. 27(2). 215.

5. Bagosi. S.: Csctenyi, I., J. Com. Concr. Res. 194. 28(12) 1753 .

6. Sandor. B.: I aszlo. I. C. Cem Concr Res.. 194\%. 29. 479.

7. Komarneti. S. Awch Chem. Waste monage, 1985, 5(4). 247.

8. Komarteni, S.: Breval, Г.: Roy, D. M.: Roy. R. Cem. Concr: Res. 1988. 18. 204.

9. I abhestwar. N.: Shrivastava. O. P. Ind. J. Chem. Soc: 1989. 27.4(11).999.

10. I abhestwar. N.: Shrivastava. O. P. Reoct Solids. $1 \% 89$. $7(3) .225$

11. Isuji. M.: Kumameni. \$. . Mater: Res.. 1989. f(3)

12. El-Koreshy: S. A. Monalshelte fur Chemie. 1997. I28. $59 \%$.

13. El-Kureshy: S. A.: Al-Wakeel. E. I. Egrpt J. Chem. 1999. $f(3) .237$.

14. Al-Wakeel. E. I.: El-Korashy. \$. A.: El-Ilemaly. \$. A.: Rizk. M. A. J. Hater: Sci. 2001. 36. 2405.

15. El-Koreshy. \$. A. Monatshelte Für Chemie. 2002. 133 (3). 333

16. Youn. J. K.: Waltraud. M. K.: Iakeshi. M. J. Mater: Res.. 1993. $8(11) .2948$.

17. Bell. G. M. M.: Bensted. I.: Glasser. F. L' Adt $6 \mathrm{em}$ Res: 1989, 2,61.

18. Ishida, H.: Mabuchi, K.: Saski, K.: Mitsuda. T. J. Amer: Cerm. Soc: 1992, 75(9), 2427

19. Heller. I. Wheral Hotg. 1953. 30, 150.

20. Komarneni. S.: Tsụi. M. J. Aner: Ceram. Sos: $1 \% 89$. $72,1668$. 